УДК 78.02: 681.82.073

Воронцов Сергій Олександрович

кандидат фізико-математичних наук, доцент, доцент кафедри теорії та методики мистецької освіти Харківський національний університет мистецтв імені І.П. Котляревського, м. Харків, Україна

ORCID ID 0000-0002-9396-0726

vorontsov@num.kharkiv.ua

\title{
МОБІЛЬНІ ПРИСТРОЇ В НАВЧАННІ ІНФОРМАЦІЙНИМ ТЕХНОЛОГІЯМ У ЗАКЛАДАХ ВИЩОЇ МИСТЕЦЬКОЇ ОСВІТИ
}

\begin{abstract}
Анотація. Розглянуто можливості застосування смартфонів для виконання різноманітних завдань у межах курсу інформаційних технологій для студентів мистецьких вишів. У статті описуються власні дослідження і напрацювання 3 широкого кола питань, пов'язаних 3 підбором i налаштуванням програмного забезпечення для створення власноруч відповідного ілюстративного матеріалу, музичного супроводу, оригінал-макетів програм концертів, афіш тощо. Показано, що смартфони вже здатні конкурувати 3 настільними комп'ютерами або ноутбуками і єдине, що накладає певні обмеження - це порівняно малий розмір екрану, через що зручність і ефективність роботи з мобільними додатками інколи поступається застосуванню відповідних програм у комп'ютерному середовищі. Розглянуто питання інтеграції мобільних пристроїв у локальну мережу навчального закладу і механізми організації зв’язку не тільки для обміну даними у вигляді файлів, а й для трансляції зображення екрану смартфона на великий екран Smart TV або комп'ютерний монітор 3 використанням бездротових протоколів Wi-Fi i Direct Wi-Fi. За результатом досліджень обрано технологію MirrorOp Sender - MirrorOp receiver, що здійснює віддзеркалення. Після практичних експериментів 3 відповідним мобільним додатком передавача і програмою приймача на платформі Windows встановлено, що подібна трансляція можлива тільки тоді, коли IP адреси смартфона і комп'ютера, до якого підключений монітор, знаходяться в одній підмережі, і у випадку, коли це не так, необхідно змінити місце фізичного підключення комп'ютера до локальної мережі. Детально розглянуто можливості і зручності таких мобільних додатків, як-от WPS Office i Canva - для компоновки текстової і графічної складової при створенні власного контенту. Практика запроваджених підходів до вивчення інформаційних технологій виявила неабиякий інтерес серед студентів, особливо тих, хто до цього використовував смартфон лише в якості телефонного апарата.
\end{abstract}

Ключові слова: мобільні пристрої; мобільні додатки; мобільне навчання; інформаційні технології; смартфон; локальна мережа.

\section{1. ВСТУП}

Постановка проблеми. Усі сучасні студенти використовують ті чи інші пристрої, що за призначенням виконують різноманітні завдання з обробки цифрової інформації, хоча і не всі віддають собі звіт і розуміються на цьому достатньою мірою. На відміну від студентів європейських або американських мистецьких коледжів, де наявність ноутбука в кожного сприймається як даність, в українських закладах мистецької освіти близько третини студентів не мають комп'ютерів взагалі, ще деяка частина 3 них мають комп'ютер тільки вдома або в іншому місті, та і належить він комусь із родини, тобто не $є$ персональним у повному розумінні. Отже, користування ноутбуком для багатьох студентів не $є$ повсякденною практикою. I тут виникає певна колізія. Програма курсу інформаційних технологій для вищих навчальних закладів культури і мистецтв III-IV рівнів акредитації грунтується на використанні в першу чергу персонального комп'ютера. Структура даної навчальної дисципліни будується на поступовому розгляді питань, починаючи з базових понять (біти, байти, пікселі, інтерфейси, драйвери, індекси кольору тощо) і налаштувань операційної системи Windows до 
створення власноруч різноманітного ілюстративного матеріалу, музичного супроводу, оригінал-макетів програм концертів, афіш, флаєрів 3 використанням можливостей офісних пакетів (Microsoft Office Word, Open Office чи якихось інших) або редактора растрової графіки (наприклад, Photoshop та ін.). Зазвичай мається на увазі, що для тих студентів, у кого немає власного комп'ютера, завдання в рамках курсу виконуються або під час занять в аудиторії, або на будь-якому іншому комп’ютері, що є власністю друзів чи знайомих. Утім на практиці в умовах, коли кількість студентів, які не користуються комп'ютером, не маючи його у власності, виявляється чималою, вимагати виконання завдань саме на цьому пристрої не завжди доцільно.

3 іншого боку, ситуація виявляється геть іншою, якщо проаналізувати використання студентами мобільних пристроїв. За останні декілька років сталися суттєві зміни і статистика охоплення населення України мобільним зв'язком вказує на те, що зараз кожна молода людина має у власності вже більше ніж один мобільний телефон, з яких принаймні один мобільний пристрій - смартфон. Як відомо, сучасні смартфони вже є досить потужними і в порівнянні з комп'ютерами не поступаються останнім ані швидкістю центрального процесора, ані обсягом оперативної пам'яті. Поки що тільки обсяг «жорсткого диску» в смартфонах - це є загальний обсяг пам'яті, такий собі твердотільний (SSD) носій - складає десь 32-64 Гб і в рази поступається традиційному жорсткому диску комп'ютера. Але це не важливо, тому що для зберігання даних широко використовуються інші сховища - хмарні сервіси або зовнішні носії. Єдине, що відрізняє традиційні пристрої обробки інформації, ноутбуки, від смартфонів - це операційна система та користувальницький інтерфейс. Слід зазначити, що такі операційні системи, як Windows, мають суттєво довший час удосконалення і розвитку, аніж Android або iOS, i тому не дивно, що відповідні програмні продукти мають порівняно вищий ступінь розвиненості. Настільні комп'ютери або ноутбуки мають якісну перевагу у зручності використання завдяки більшим фізичним розмірам та наявності мишки.

Утім, суттєвою перевагою смартфонів $€$ їх майже стовідсоткова доступність: кожен студент має такий пристрій у власному розпорядженні і щоденно користується ним тією чи іншою мірою. Тому дослідження шляхів використання мобільних пристроїв сьогодні $є$ доволі актуальним. Задача курсу інформаційних технологій полягає також у тому, щоб розширити коло завдань, що виконуються за допомогою смартфона, і вийти за межі використання його лише в якості телефонного апарата. Тим більше, що для цього вже напрацьована величезна кількість прикладних програм, доступних для завантаження через Play Market або App Store, і достатньо лише встановити потрібний додаток на власному смартфоні.

Аналіз останніх досліджень і публікацій. Головним завданням мистецької освіти є не тільки підготовка фахівця, здатного професійно виконувати музичні твори або театральні ролі, а також, і навіть в першу чергу, виховання творчої особистості. Сьогодні активно розглядаються інтеграційні процеси в професійній підготовці музикантів як основа їх духовного розвитку [1], [2]. Питання комп’ютеризації навчання теж розглядаються і вивчаються фахівцями навчальних предметних середовищ, а проблеми використання інформаційних технологій у навчанні постійно досліджуються в наукових виданнях. Існує велика кількість та різноманітність напрямків досліджень, зокрема вивчення різних аспектів запровадження інформаційно-комунікаційних технологій в освітню практику, пов'язаних з використанням мобільних пристроїв. Узагальнюючи закордонний досвід, представлений у відкритих наукометричних базах, слід зазначити, що з появою загальнодоступних і недорогих мобільних та бездротових пристроїв, педагогічні вимоги до мобільного навчання було сформульовано ще в 2015 році. Тоді А. Джаліл (А. Jalil), М. Бір (М. Beer), П. Кроутер (Р. Crowther) [3] показали, 
що педагогічно обгрунтований дизайн для розвитку мобільних додатків $є$ ключовим фактором забезпечення приємного та насиченого досвіду навчання в мобільному середовищі, оскільки викладачі та студенти починають усвідомлювати важливість подолання розриву між формальним аудиторним та позакласним неформальним навчанням для досягнення педагогічних цілей. Того ж року Г. Торстейнссон (G. Thorsteinsson), Р. Гуннарсдоттір (R. Gunnarsdottir), А. Нікулеску (А. Niculescu) [4] також визначили роль мобільних технологій у студентському середовищі, коли використання сучасних мобільних пристроїв забезпечує багатоканальну підтримку навчання всередині аудиторії та активізацію взаємодії між студентами. Перше наближення до вивчення мобільних додатків для цілей медичної освіти зробили Л.B. Понсе (L.B. Ponce) Дж.А.Дж. Мендез (J. А. J. Méndez), Ф.Дж,Дж. Пехальво (F. J. G. Peñalvo) [5]. Розробку та тестування комплексної мобільної системи навчання за допомогою проєктних рішень на основі дизайну здійснили Н. О. Кескин (N.O. Keskin), А. Кузу (A. Kuzu) [6]. Ними було розроблено мобільний додаток на платформі iOS i було встановлено, що така система може дати позитивний внесок у професійний розвиток науковців. Досліджуючи додатки для соціальних мереж, які створюють середовища, повні взаємодії, і стимули, необхідні для освіти, А.C. Дрігас (A.S. Drigas), П. Ангелідакіс (P. Angelidakis) [7] наводять достатньо доказів того, що програми mlearning, якщо вони поєднують використання нових технологічних можливостей i педагогіку, можуть бути досить популярними. Використання мобільних додатків в освіті та вплив цифрових журналів на навчання студентів досліджували С. ЛунаНеварец (С. Luna-Nevarez), Е. МакГоверн (E. McGovern) [8]. Продуктивний підхід до залучення мобільних додатків в галузі освіти застосував П. Сагар (P. Sagar) [9], пропонуючи загальні рекомендації для власників навчальних закладів. Згідно 3 останнім дослідженням Н. Шасті (N. Shastri) [10], час, витрачений студентами на освітні програми, збільшується, мобільні додатки мають певну цінність для диверсифікації навчання та створення доступного навчального середовища, хоча студенти все ще витрачають значну кількість часу на програми соціальних мереж.

В Україні останнім часом 3'явились дослідження 3 методики використання мобільних пристроїв для навчання фізики [11] - [13], електромеханіки [14], розроблення дизайн-продукту в навчанні майбутніх фахівців з дизайну [15] та інших дисциплін [16]. Утім, окрім методологічних питань, нас цікавлять також технічні аспекти організації навчання інформаційних технологій, оскільки вони створюють передумови запровадження мобільних пристроїв в практику мистецької освіти.

Метою статті $\epsilon$ аналіз використання мобільних пристроїв, першочергово смартфонів, та сучасного програмного забезпечення в ході вивчення інформаційних технологій у закладах вищої мистецької освіти, що дозволяють набути певні практичні навички, розвинути зацікавленість та вмотивованість студентів у вивченні дисципліни, а також підвищити креативність навчального процесу загалом.

\section{2. РЕЗУЛЬТАТИ ДОСЛІДЖЕННЯ}

Завданням цієї статті було дослідити, яким чином залучення мобільних пристроїв під керуванням операційних систем Android або iOS до виконання традиційних завдань, які зазвичай виконуються за допомогою комп'ютера, дозволяє підвищити рівень успішності студентів і розвинути зацікавленість у вивченні інформаційних технологій. Завдання курсу, які можливо виконувати маючи в розпорядженні лише смартфон, значно відрізняються рівнем складності, до того ж виконання певних завдань потребує відповідного рівня обізнаності. 
Під час вивчення властивостей аналогового звуку та аналогового звукозапису доволі ефективним засобом $є$ наочна демонстрація звуковисотності за допомогою смартфона. Для цього достатньо лише відвідати сайт генератора звуків онлайн [17] у всесвітній павутині і ввімкнути програвання звукового тону залежно від частоти. Звичайно, молодь сприймає таку можливість з легкістю, не замислюючись над тим, що ще не так і давно, усього пару десятиріч тому, така демонстрація була можливою тільки за умови фізичної наявності відповідних приладів, тобто тон-генератора, підсилювача звукової частоти і гучномовця.

У подальшому дослідженні звукових коливань акустичних музичних інструментів для кращого розуміння процесу цифрового звукозапису досить корисною $є$ наочна демонстрація графічного зображення звукових даних, які представляються у вигляді послідовності відліків амплітуди звукового сигналу, об'єднаних однією обвідною, тобто у вигляді так званої сигналограмми або хвильової форми. Зазвичай це зручно робити за допомогою будь-якої програми аудіоредактора [18]. Серед великої кількості останніх можна виділити програму WavePad, яка є безкоштовною і доступною для завантаження для мобільних пристроїв на відміну від більшості розвинутих аудіоредакторів, що існують лише у варіанті для операційних систем Windows aбо Mac OS. Якщо далі занурюватися в коло питань, пов'язаних з використанням можливостей редагування цифрового звуку, то слід розглянути поняття цифрової звукової робочої станції (англ. digital audio workstation, DAW). Дивовижно, але принаймні для смартфонів на Android вже існує безкоштовний додаток Audiosdroid Audio Studio DAW, за допомогою якого можливо здійснити накладення голосу на музичний супровід і конвертувати отриманий результат у формат mp3. Хоча слід визнати, що ця програма, як і більшість аудіоредакторів на Android, є недосконалою, а її робота доволі нестабільною, тому для отримання практичного результату поки що бажано користатись комп'ютером - час Android смартфонів тут ще не настав.

Проте існує багато корисних мобільних додатків саме для музикантів. Це досить прості прилади, що зараз стали віртуальними, як-от метроном або тюнер. Ясна річ, настроювання музичних інструментів традиційно здійснюється по камертону. Утім використання камертона вимагає наявності гарного музичного слуху, а от за допомогою тюнера інструмент можна настроїти навіть за його відсутності. Найчастіше тюнер являє собою окремий електронний пристрій, обладнаний прищепкою, що дає можливість установити механічний контакт і вловлювати коливання безпосередньо деки музичного інструменту для порівняння його частоти 3 частотою еталону. Це дозволяє точно настроїти інструмент навіть при значному шумі.

Програмні тюнері діють аналогічно, хоча в якості приймача звукових коливань для аналізу частоти музичного тону використовується мікрофон мобільного пристрою. Останнім часом з'явилась достатня кількість додатків для Android та iOS, хоча універсальної програми, яка би випередила конкурентів і була успішною для обох класів пристроїв, поки не існує. Тим не менш, для Android пристроїв зараз можна виділити такий зручний і досить точний тюнер як Instrument Tuner. За допомогою цього додатку можна настроювати не тільки гітару, що $є$ найбільш поширеним випадком використання тюнерів, але й смичкові інструменти, такі як скрипка, альт або віолончель. Точність настройки $є$ дивовижною, вона відображається в центах (рівномірно темперований півтон складається із 100 центів), водночас похибка у вимірюванні частоти виявляється меншою, аніж похибка, що виникає внаслідок відхилень у звуковидобуванні і є залежною від швидкості і сили притиску смичка до струни.

Використання Instrument Tuner можливе навіть для настройки фортепіано, бо в ньому є ще й хроматичний тюнер. Утім коли йдеться про піаніно або рояль, то потрібно 
мати не тільки тюнер і гарний слух, але ще рояльний ключ i досвід. Тому для виконавців піаністів краще обмежитися лише контрольною функцією і в разі потреби перевірити точність настройки інструменту шляхом використання такого додатку, як Pitch Detector. За допомогою мікрофону програма «слухає» ноту, яку було натиснуто на клавіатурі, і показує ії частоту. У такий спосіб можна з легкістю визначити, чи строй фортепіано відрізняється від стандарту 440 Гц та чи немає фальшивих нот на клавіатурі. Взагалі за допомогою цього додатку легко і зручно перевірити чистоту тієї чи іншої ноти будь-якого інструменту.

Важливою частиною курсу інформаційних технології $\epsilon$ набуття навичок у створенні презентацій. Завдання полягає не тільки в тому, щоб освоїти саму програму для створення і показу презентацій, це може бути, наприклад, Microsoft PowerPoint, OpenOffice Impress або щось інше (при роботі на комп’ютері), але також продемонструвати вміння чітко розповісти презентацію, що потребує певних або хоча б мінімальних навичок ораторського мистецтва. Для студентів акторського відділення та театру анімації цей аспект презентації виявляється особливо важливим. Врешті решт, як зазначено в [19], головним у презентації $є$ те, що розповідає доповідач, а зображення на екрані лише допоміжний матеріал.

Однак для тих студентів, що не мають комп'ютера, постає вибір - або проситися до когось по тимчасовий доступ до ПК, або використовувати власний, хоч і не такий пристосований для цього, мобільний пристрій, тобто смартфон. Певна частина студентів обирає останнє, і це їх свідомий вибір, який слід поважати.

Слід зазначити, що вибір програмного забезпечення для створювання презентації, що зазвичай входить до складу будь-якого офісного пакету, доволі широкий. Тут i добре знайомий Microsoft Office для платформи Android або iOS і пакети, що не мають представництва на платформі Windows, як-от: SmartOffice, Polaris Office, WPS, що розробляється компанією Kingsoft Office Software Corp. Ltd. Також у Play Market $€$ достатня кількість додатків для фото слайд-шоу, що мають на меті створювання фото колажів у музичному супроводі, але це вже дещо інше призначення i воно не стосується власне презентацій, що повинні мати формат, сумісний з ppt або pptx.

Такий формат потрібен для того, щоб файл презентації потім можна було завантажити на комп'ютер і там здійснити демонстрацію в режимі показу слайдів.

Підсумовуючи практичний досвід, можна зробити висновок, що найбільш комфортним для роботи є WPS Office, натомість мобільна версія Microsoft Office, на відміну від загально відомої версії для OC Windows, не є цілком прийнятною для виконання практичних завдань за допомогою смартфона бо значно поступається у зручності.

На даному етапі також постає досить цікавий виклик - демонструвати презентацію на смартфоні, і водночас здійснювати передачу відображення слайдів на екран більшого розміру, наприклад, монітор комп'ютера або Smart TV, для того, щоб аудиторія мала можливість щось бачити, а не тальки слухати доповідача. При наявності останнього все досить просто: лише потрібно в налаштуваннях смартфона увімкнути режим на кшталт Smart View, якщо це смартфон виробництва Samsung, B інших виробників такий режим дистанційного відображення має іншу назву, але суть залишається незмінною - потрібно щоб смартфон «домовився» із Smart TV про спільну дію, перший транслює, а другий відображає картинку. В основі трансляції використання протоколу бездротового обміну даними типа Direct Wi-Fi.

У разі, якщо в наявності лише комп'ютерний монітор, ситуація дещо ускладнюється, але все ж таки завдання не є нездійсненним. Для початку треба зрозуміти, у який спосіб, тобто за допомогою якого саме бездротового протоколу обміну, цифрові дані із смартфона будуть потрапляти на комп'ютер, до якого 
підключений той монітор. Зрозуміло, що звичайний монітор сам по собі не може приймати радіосигнал, тому без комп'ютера не обійтись. Протокол Bluetooth не підходить, до того ж настільний комп'ютер, на відміну від ноутбука, майже ніколи на обладнаний приймачем Bluetooth. Тому залишається тільки $\mathrm{Wi}-\mathrm{Fi}$, який $\epsilon$ загальнодоступним засобом бездротової передачі даних. Далі необхідно визначитись, яке саме програмне забезпечення $\epsilon$ придатним для поєднання смартфона 3 комп'ютером. На першій погляд, якщо дивитись у Play Market, то здається, що існує достатній вибір додатків, які здійснюють зв'язок смартфона 3 комп'ютером. Але $є$ декілька зауважень. Більшість подібних програм лише забезпечують видимість мобільного пристрою в операційній системі Windows для обміну даними у вигляді обміну файлами, і це не стосується відображення екрану. А серед тих, що є у вільному доступі, або частково безкоштовних додатків, які начебто повинні забезпечувати подібну функцію, неможливо знайти щось придатне до роботи.

Тим не менше нам вдалося налагодити поєднання смартфона 3 комп'ютером для передачі зображення його екрану на монітор. Для цього було застосовано технологію MirrorOp [20] компанії Awind, тобто віддзеркалення. На жаль, після купівлі цієї технології компанією Вагсо подальша іï підтримка була призупинена в липні 2019 року. Хоча програма MirrorOp Receiver для операційної системи Windows як і раніше знаходиться у вільному доступі [21]. Після завантаження і запуску програми вона показує пусте вікно і видає повідомлення, що очікує прийом зображення за IP-адресою 192.168.1.xxx, тобто за тією адресою, яка прописана для активного мережевого адаптера, відповідального за з’єднання 3 маршрутизатором (роутером), що є вищестоящім шлюзом локальної мережі.

Отже, перша половина справи нами зроблена, i приймач, а саме програма MirrorOp Receiver, знаходиться в режими очікування зображення від іншого пристрою (мобільного, чи стаціонарного - не важливо), на якому буде запроваджено роботу передавача у вигляді програми MirrorOp Sender.

На даному етапі саме час пояснити, що комунікація приймача і передавача MirrorOp можлива тільки в разі, коли обидва пристрої знаходяться в межах однієї й тієї ж підмережі. Найпростіша конфігурація обладнання має такий вигляд. Для забезпечення доступу мобільних пристроїв до мережі Інтернет необхідно мати Wi-Fi роутер (найчастіше це D-Link або TP-Link). Зазвичай такий роутер має ще й 4 мережевих Ethernet порта для дротового підключення. Так от, комп'ютер необхідно підключити до одного $з$ цих чотирьох портів для того, щоб передавач його «побачив». Зрозуміло, що якщо комп'ютер був підключений інакше, найвірогідніше він зазвичай $\epsilon$ підключеним до іншого шлюзу, того куди підключений Wan порт Wi-Fi роутера, то необхідно змінити IP-адресу шлюзу в налагодженнях мережевого адаптера.

Після цього програму MirrorOp Receiver на комп'ютері необхідно запустити заново, щоб зміни мали ефект і тоді можна перейти до справи пошуку і налагодження передавача MirrorOp Sender на мобільному пристрої. Ось тут може чекати найскладніше. Біда полягає в тому, що версія MirrorOp Sender, яку можна завантажити iз Play Market, швидше за все виявиться непридатною до практичної роботи. Після встановлення цього додатку (і на даному етапі також можливі проблеми) і спроби його запустити програма видає помилку і закривається.

Але на просторах Інтернету нам вдалося знайти робочу версію MirrorOp Sender (1.2.1.0), яка не видає ніяких помилок, а чудово працює. Після запуску програми вона одразу повідомляє, що в мережі знайдено приймач MirrorOp Receiver i можна розпочати трансляцію, натиснувши кнопочку з такою ж самою назвою. Як можна уявити, в аудиторії виникає певний ентузіазм, коли студенти бачать, що на моніторі 
комп'ютера дублюється зображення з екрана смартфона. Для оптимізаціі зображення на моніторі смартфон краще тримати горизонтально.

Після того, як зв'язок смартфона 3 «великим екраном» налагоджено, маючи високотехнологічний допоміжний матеріал, можна розпочинати саму презентацію. Слід зазначити, що, на відміну від режиму Smart View iз Smart TV, у даному випадку передається тільки зображення, а не звук. Але зробити «великий» звук із смартфона значно простіше, і якщо в наявності $є$ акустичні колонки з Bluetooth, то достатньо лише увімкнути цей бездротовий протокол на смартфоні і здійснити його спаровування 3 колонками (не з комп'ютером, бо там блютуса немає).

Наступне коло завдань - це підготовка друкованої продукції, що супроводжує професійну діяльність музикантів: виконавців, музикознавців, композиторів, а також митців, пов'язаних з театром: акторів драми, акторів театру анімації та режисерів. Зрозуміло, якщо йдеться про відомих музикантів або акторів, чий гастрольний графік розписаний на місяці або навіть роки наперед, то такі дрібні повсякденні справи, як підготовка програми концерту, що іноді роздається слухачам у глядацькій залі, або афіш чи флаєрів, призначених для розповсюдження інформації про концерти і вистави, це все лягає на плечі адміністратора або імпресаріо і зрештою виконується професійними фахівцями на замовлення. Маестро такими справами не переймаються.

А от поки ще молоді виконавці не мають власних імпресаріо, треба робити подібні речи самотужки, бо інакше доведеться звертатися по допомогу до друзів і знайомих. Ось тут спроможність виготовити ці атрибути власноруч за допомогою персонального комп'ютера або смартфона, виявивши художній смак і навички графічного дизайну, виявляється вельми доречною.

Сфокусуємо увагу лише на використанні смартфона. Як і для платформи Windows, для мобільних операційних систем існує спеціалізоване програмне забезпечення для підготовки друкованою продукції на зразок Publisher у пакеті Microsoft Office. Утім поглиблене вивчення таких мобільних додатків не здається доцільним принаймні з двох причин - по-перше, навряд чи студенти, що здобувають мистецьку освіту, мають на меті професійну діяльність у якості дизайнерів друкованої продукції, а по-друге, навіть якщо і так, то більш ефективно це робити в комп'ютерному середовищі.

Тут знову ж таки на допомогу приходить вищезгаданий WPS Office, який виявляється досить зручним і дозволяє роботу з колонками. Як відомо, журнальна або газетна верстка відрізняється від книжкової тим, що сторінка має не одну, а дві, три і навіть більше колонок тексту. Для програмки концерту слід змінити орієнтацію сторінки 3 книжкової на альбомну і в налаштуваннях розмітки вибрати 3 колонки для тексту. Отже, завдання зводиться до підготовки двох сторінок тексту аркушу A4 3 додаванням деяких графічних чорно-білих елементів гравюрного типу або ч/б малюнків. Одна сторінка - то обкладинка, а інша сторінка містить, а на другій - сама програмка. Роздрукувати таку програмку на лазерному принтері і потім зігнути іiі втричі не складно, але результат матиме пристойний вигляд.

Незважаючи на вищезгадані зауваження стосовно доцільності поглибленого вивчення спеціалізованих дизайнерських програм, серед них все ж $\epsilon$ такі, що поєднують у собі простоту використання і ефективність. Тут слід обов'язково згадати програму Canva [22], яка являе собою спрощений інструмент графічного дизайну, що використовує функцію перетягування елементів та забезпечує доступ до фотографій, векторних зображень, графіки та шрифтів. Сьогодні концепція, яку використовує програма Canva, стрімко набирає обертів і стає все більш популярною завдяки простоті i зручності. Вона існує на всіх платформах, а також доступна у вигляді онлайн сервісу. Кількість користувачів вимірюється вже сотнями мільйонів. Сервіс Canva $€$ 
інтегрованим 3 хмарними технологіями Dropbox [23] для того, щоб зробити доступними для своїх користувачів мільйони дизайнерських фотографій, зображень та елементів графічного дизайну. Ще один аспект заслуговує бути згаданим - це вдале поєднання технологією Canva безкоштовних рішень, функцій та елементів і платного контенту. Завдяки цьому вона $є$ дуже привабливою, і цей інструмент використовують як дизайнери-початківці, так і професіонали.

Із врахуванням цього можна сміливо встановлювати додаток Canva на власний смартфон, не важливо це Android-пристрій чи айфон. Сдине, на що слід обов'язково звернути увагу, якщо на меті є створення друкованою продукції, - це щільність друку, або DPI [24] - кількість точок на дюйм. На практиці це зводиться до правильного вибору розміру сторінки для друкованого відбитку. Наприклад, якщо нас цікавить виготовлення афіші, то, ймовірно, вона повинна мати розмір А3 або навіть більше. Тому в налаштуваннях додатку Canva необхідно вибрати відповідний розмір, бо інакше по замовчуванню буде встановлено досить маленькій розмір, 3 якого можна роздрукувати хіба що обгортку для невеличкої шоколадки.

Але саме тут криється обмеження. На платформі Android у безкоштовному варіанті можна вибрати тільки розмір паперу А5, а встановлення більшого стандарту можливо тільки в платній версії. Утім, якщо подивитися уважно, то в безкоштовній версії таки є можливість задати розмір А3. Для цього потрібно лише задати розмір у міліметрах, пам'ятаючи про те, що A3 це є 297x420 мм. На платформі iOS ще простіше, A3 в безкоштовній версії немає, але є A2. По завершенні роботи над виготовленням графічного дизайну афіші результат можна конвертувати в формат PDF.

\section{3. ВИСНОВКИ ТА ПЕРСПЕКТИВИ ПОДАЛЬШИХ ДОСЛІДЖЕНЬ}

Мобільні пристрої вже стали невід'ємною частиною повсякденного життя і, що важливо, основними засобами для споживання контенту. Згідно 3 останнім дослідженням від аналітиків з ComScore [25], [26] в зрізі користувачів у віці від 18 і до 34 років, практично більше не використовуються традиційні комп'ютери для перегляду контенту в мережі. Тому при вивченні методики та підходів до викладання інформаційних технологій у вишах мистецької освіти цей аспект теж має бути врахований. У статті викладені результати дослідження основних шляхів використання мобільних пристроїв для виконання завдань по створенню власного мультимедійного матеріалу і надано практичні рекомендації по вибору та налаштуванням відповідних мобільних додатків. Напрацьовані рекомендації щодо використання розглянутих мобільних додатків при виконанні завдань 3 курсу інформаційних технологій для студентів вищих навчальних закладів мистецької освіти III-IV рівнів акредитації. Попри деякий песимізм щодо можливостей зі створення контенту за допомогою мобільних технологій, вони торують свій шлях і впевнено займають великі ніші там, де раніше панували лише традиційні комп'ютери, наприклад вебдизайн, графічний дизайн тощо. Однак загальна збудженість та ентузіазм щодо подальшого стрімкого збільшення використання мобільних пристроїв повинні мати певні межі. Якщо придивитися уважно, то можна зрозуміти, що з використанням мобільних додатків створюється дещо інший графічний або мультимедійний матеріал, аніж той, що створюється на великих моніторах настільних комп'ютерів. Він теж $є$ затребуваним і іноді навіть досконалим, але він іншій. Серед студентів іноді знаходяться ентузіасти, котрі принципово намагаються виконувати складні завдання виключно на смартфоні, хоча це іноді нагадує будування мініатюрного корабля всередині пляшки.

За результатом дослідження було зроблено висновок, що заохочення студентів до використання мобільних пристроїв у ході виконання домашніх завдань 3 курсу 
інформаційних технологій призводить до помітного підвищення рівня якості їх виконання. Цьому існує просте пояснення - значно вищий рівень доступності мобільних пристроїв порівняно з традиційними комп'ютерами. Загалом це також дозволяє підвищити рівень успішності студентів і розвинути їх зацікавленість у вивченні ІКТ.

Проаналізовано стратегію розбудови навчального процесу із залученням мобільних технологій та перспективи їх подальшого розвитку. Враховуючи особливості застосування мобільних пристроїв у ході професійної підготовки музиканта або актора та маючи на меті виховання творчої особистості, вказана можливість доповнення сілабусу питаннями розгляду відповідних мобільних додатків для створення власного контенту.

Варто очікувати, що рівень досконалості мобільних додатків для створення мультимедійного контенту буде надалі підвищуватися, і в першу чергу це стосується Android пристроїв.

Подальші зусилля варто спрямувати на дослідження дистанційної комунікації викладача з аудиторією під час лекції або в ході індивідуальних занять у вишах мистецької освіти за умови використання ними мобільних пристроїв.

\section{СПИСОК ВИКОРИСТАНИХ ДЖЕРЕЛ}

[1] I. I. Полубоярина, “Інтеграційні процеси в професійній підготовці музикантів як основа їхнього духовного розвитку ”, Музичне мистечтво в освітологічному дискурсі, № 3, с. 97-102, 2018. [Електронний ресурс]. Доступно: http://nbuv.gov.ua/UJRN/maed_2018_3_20. Дата звернення: Січ. 12,2020 .

[2] Poluboyarina, I. Pristalov, "Innovative methods in forming performing mastery of students-musicians", Традищии и новачии в высшем архитектурно-художественном образовании, №1, c.82-84, 2016.

[3] A. Jalil, M. Beer, P. Crowther, "Pedagogical Requirements for Mobile Learning: A Review on MOBIlearn Task Model", Journal of Interactive Media in Education, 2015(1), p.Art. 12. DOI: http://doi.org/10.5334/jime.ap [Електронний pecypc]. Доступно: https://wwwjime.open.ac.uk/articles/10.5334/jime.ap/. Дата звернення: Січ. 12,2020.

[4] G. Thorsteinsson, R. Gunnarsdottir, A. Niculescu, "Assessing the Value of a Mobile Application in Fostering Ideation within a School Context", Studies in Informatics and Control, Vol. 24, No. 1, p. 119126, 2015.2 [Електронний ресурс]. Доступно: https://opinvisindi.is/bitstream/handle/20.500.11815/450/SIC_2015-1-Art13.pdf?sequence=1. Дата звернення: Січ. 12,2020.

[5] L.B. Ponce, J. A. J. Méndez, F. J. G. Peñalvo, "First approach of mobile applications study for medical education purposes" [Електронний десурс]. Доступно: https://www.researchgate.net/profile/Laura_Briz/publication/268387987_First_approach_of_mobile_appli cations_study_for_medical_Education_purposes/links/54816f7a0cf20f081e727865.pdf. Дата звернення: Січ. 12,2020 .

[6] N.O. Keskin, A. Kuzu, "Development and testing of a m-learning system for the professional development of academics through design-based action research" [Електронний ресурс]. Доступно: http://www.irrodl.org/index.php/irrodl/article/view/1613/3194. Дата звернення: Січ. 12,2020.

[7] A.S. Drigas, P. Angelidakis, "Mobile Applications within Education - An Overview of Application Paradigms in Specific Categories", International Journal of Interactive Mobile Technologies, Vol. 11, №4, 2017. [Електронний pесурс]. Доступно: https://online-journals.org/index.php/ijim/article/view/6589, Дата звернення: Січ. 12,2020.

[8] C. Luna-Nevarez, E. McGovern, "On the Use of Mobile Apps in Education: The Impact of Digital Magazines on Student Learning", Journal of Educational Technology Systems, Vol. 47(1), p. 17-31, 2018. [Електронний ресурс]. Доступно: https://journals.sagepub.com/doi/pdf/10.1177/0047239518778514. Дата звернення: Січ. 12,2020.

[9] P. Sagar, "Mobile Apps In The Education Industry: A Productive Approach", 2019. [Електронний pecypc]. Доступно: https://elearningindustry.com/mobile-apps-in-the-education-industry-productiveapproach. Дата звернення: Січ. 12,2020. 
[10] N. Shastri, "How Mobile Apps Are Transforming the Education Industry", The Manifest, 2019. [Електронний peсурс]. Доступно: https://themanifest.com/app-development/how-mobile-appstransforming-education-industry. Дата звернення: Січ. 12,2020.

[11] М. Осипчук, “Мобільні технології як перспективний засіб навчання фізики” . Матеріали II Міжнародної студентської науково-технічної конферениї „Природничі та гуманітарні науки. Актуальні питання", 25-26 квітня 2019, Т. : ТНТУ, с. 188-189, 2019. [Електронний ресурс]. Доступно: http://elartu.tntu.edu.ua/handle/lib/28402. Дата звернення: Січ. 12,2020.

[12] I.В. Сальник, “ Мобільні пристрої та сучасне освітнє програмне забезпечення у навчанні фізики в закладах загальної середньої освіти”, Інформаційні технології $і$ засоби навчання, том 73, №5, с.114, 2019. [Електронний ресурс]. Доступно: https://journal.iitta.gov.ua/index.php/itlt/article/view/2918/1561. Дата звернення: Січ. 12,2020.

[13] С. С. Пудова, “Використання мобільного телефону в навчальному процесі” / Фізико-математична освіта : науковий журнал / Міністерство освіти i науки України, Сумський державний педагогічний університет імені А. С. Макаренка,- Суми : Вид-во СумДПУ імені А. С. Макаренка, Вип. 2 (16), с. 97-101, 2018. [Електронний ресурс]. Доступно: https://repository.sspu.sumy.ua/handle/123456789/5412 . Дата звернення: Січ. 12,2020.

[14] Y.O. Modlo, S.O. Semerikov, P.P. Nechypurenko, S.L. Bondarevsky, O.M. Bondarevska and S.T. Tolmachev, "The use of mobile Internet devices in the formation of ICT component of bachelors in electromechanics competency in modeling of technical objects", Semantic Scholar, p. 413-428, 2019. [Електронний ресурс]. Доступно: https://www.semanticscholar.org/paper/The-use-of-mobile-Internetdevices-in-the-formation-Modlo-Semerikov/151b9ebf97670c30f8b21420ec5da7362f6afb9. Дата звернення: Січ. 12,2020.

[15] Д.В. Борисенко, “ Використання мобільних додатків при розроблені дизайн-продукту у навчанні майбутніх фахівців з дизайну”, Інформащійні технології $і$ засоби навчання, том 68, №6, с.47-63, 2018. [Електронний ресурс]. Доступн: https://journal.iitta.gov.ua/index.php/itlt/article/download/2224/1412. Дата звернення: Січ. 12,2020.

[16] Л. Дибкова, "Перспективи електронного навчання у 21 столітті за допомогою застосування мобільних девайсів” / Молодь і ринок №9 (176), с. 50-54, 2019. [Електронний ресурс]. Доступно: http://mir.dspu.edu.ua/article/download/182054/181967. Дата звернення: Січ. 12,2020.

[17] T. Szynalski, “Online Tone Generator - generates pure tones of any frequency”. [Електронний ресурс]. Доступно: https://www.szynalski.com/tone-generator/. Дата звернення: Січ. 12,2020.

[18] Матеріал з Вікіпедії - вільної енциклопедії, “Аудіоредактор”. [Електронний ресурс]. Доступно: https://uk.wikipedia.org/wiki/Аудіоредактор. Дата звернення: Січ. 12,2020.

[19] Б. Буник, “Як зробити презентацію краще”, 2014. [Електронний ресурс]. Доступно: https://bunyk.wordpress.com/2014/12/07/how-to-present/. Дата звернення: Січ. 12,2020.

[20] "Screen mirroring MirrorOpt technology for mobile devices". [Електронний ресурс]. Доступно: https://www.mirrorop.com/. Дата звернення: Січ. 12,2020.

[21] "Mirroring software application for wePresent systems". [Електронний ресурс]. Доступно: https://www.barco.com/en/product/mirrorop. Дата звернення: Січ. 12,2020.

[22] “Програмне забезпечення Canva - чудові графічні зображення безкоштовно”. [Електронний pecypc]. Доступно: https://www.canva.com. Дата звернення: Січ. 12,2020.

[23] D. Houston, A. Ferdowski, “Dropbox - файлообмінник та синхронізатор файлів”. [Електронний pecypc]. Доступно: https://uk.wikipedia.org/wiki/Dropbox. Дата звернення: Січ. 12,2020.

[24] Матеріал 3 Вікіпедії - вільної енциклопедії, “Роздільна здатність”. [Електронний ресурс]. Доступно: https://uk.wikipedia.org/wiki/Dots_per_inch. Дата звернення: Січ. 12,2020.

[25] Матеріал з Вікіпедії - вільної енциклопедії, “Cömscore - компанія з вимірювання та аналізу засобів масової інформації”. [Електронний ресурс]. Доступно: https://en.wikipedia.org/wiki/Comscore. Дата звернення: Січ. 12,2020.

[26] K. Lewis, "Global State of Mobile”, Comscore Whitepaper, 2019. [Електронний ресурс]. Доступно: https://www.comscore.com/Insights/Presentations-and-Whitepapers/2019/Global-State-of-Mobile. Дата звернення: Січ. 12,2020. 


\title{
МОБИЛЬНЫЕ УСТРОЙСТВА В ОБУЧЕНИИ ИНФОРМАЦИОННЫМ ТЕХНОЛОГИЯМ В УЧРЕЖДЕНИЯХ ВЫСШЕГО ХУДОЖЕСТВЕННОГО ОБРАЗОВАНИЯ
}

\author{
Воронцов Сергей Александрович \\ кандидат физико-математических наук, доцент, \\ доцент кафедры теории и методики художественного образования \\ Харьковский национальный университет искусств имени И.П. Котляревского, г. Харьков, Украина \\ ORCID ID 0000-0002-9396-0726 \\ vorontsov@num.kharkiv.ua
}

\begin{abstract}
Аннотация. Рассмотрены возможности применения смартфонов для выполнения различных задач в рамках курса информационных технологий для студентов художественных вузов. В статье описываются собственные исследования и наработки по широкому кругу вопросов, связанных с подбором и настройкой программного обеспечения для создания собственноручно соответствующего иллюстративного материала, музыкального сопровождения, оригинал-макетов программ концертов, афиш и т. п. Показано, что смартфоны уже способны конкурировать с настольными компьютерами или ноутбуками и единственное, что накладывает определенные ограничения - это сравнительно малый размер экрана, поэтому удобство и эффективность работы с мобильными приложениями иногда уступает применению соответствующих программ в компьютерной среде. Рассмотрены вопросы интеграции мобильных устройств в локальную сеть учебного заведения и механизмы организации связи не только для обмена данными в виде файлов, но и для трансляции изображения экрана смартфона на большой экран Smart TV или компьютерный монитор с использованием беспроводных протоколов Wi-Fi и Direct Wi-Fi. По результатам исследований выбрана технология MirrorOp Sender - MirrorOp receiver, осуществляющая отображение. После практических экспериментов с соответствующим мобильным приложением передатчика и программой приемника на платформе Windows установлено, что подобная трансляция возможна только тогда, когда IP-адреса смартфона и компьютера, к которому подключен монитор, находятся в одной подсети, и в случае, если это не так, необходимо изменить место физического подключения компьютера к локальной сети. Подробно рассмотрены возможности и удобства мобильных приложений, таких как WPS Office и Canva, для компоновки текстовой и графической составляющей при создании собственного контента. Практика используемых подходов к изучению информационных технологий показала определенный интерес среди студентов, особенно тех, кто до этого использовал смартфон только в качестве телефонного аппарата.
\end{abstract}

Ключевые слова: мобильные устройства; мобильные приложения; мобильное обучение; информационные технологии; смартфон; локальная сеть.

\section{MOBILE DEVICES IN TEACHING INFORMATION TECHNOLOGIES AT INSTITUTIONS OF HIGHER ART EDUCATION}

\author{
Sergei A. Vorontsov \\ $\mathrm{PhD}$ of Physical and Mathematical Sciences, \\ Associate Professor, Department of Theory and Methodology of Art Education \\ Kharkiv I. P. Kotlyarevsky National University of Arts, Kharkiv, Ukraine \\ ORCID ID 0000-0002-9396-0726 \\ vorontsov@num.kharkiv.ua
}

\begin{abstract}
The possibilities of using smartphones to perform various tasks within the scope of the course of information technologies for students of art universities are considered. The article describes research and analysis on a wide range of issues related to the choice and setup of software for creating their own illustrative material, musical accompaniment, print ready compilations of concert programs, posters, playbills, etc. It is shown that smartphones are already able to compete with desktop computers or laptops and the only thing that imposes certain limitations is relatively small screen size due to which the convenience and efficiency of working
\end{abstract}


with mobile applications is sometimes inferior to the use of appropriate programs in a computer environment. The issues of the integration of mobile devices into the local network of the educational institution and communication techniques not only for exchanging data in the form of files, but also for screen mirroring of the smartphone to larger screen of a Smart TV or computer monitor using wireless protocols Wi-Fi and Direct Wi-Fi . Based on research results, the MirrorOp Sender - MirrorOp Receiver technology, that implements the mirroring, was selected. After practical experiments with the corresponding mobile sender application and receiver program on the Windows platform, it was found out that such broadcast is possible only when the IP addresses of the smartphone and the computer to which the monitor is connected are on the same subnet, and if this is not the case, it is necessary to change the physical connection of the computer to the local network. The capabilities and conveniences of mobile applications such as WPS Office and the Canva graphic-design tool for composing text and graphic components when creating your own content are examined in detail. The practice of the approaches used to study information technologies showed an interest of the students, particular of those who had previously used a smartphone only as a telephone.

Keywords: mobile devices; mobile applications; mobile training; information technologies; smartphone; local network.

\section{REFERENCES (TRANSLATED AND TRANSLITERATED)}

[1] I. Poluboyarina, "Integration processes in professional training of musicians as a basis for their spiritual development ", Muzychne mystetstvo v osvitologichnomu dyskursi, no. 3, pp. 97-102, 2018. [Online]. Available: http://nbuv.gov.ua/UJRN/maed_2018_3_20. Accessed on: Jan.12,2020. (in Ukrainian)

[2] I. Poluboyarina, I. Pristalov, "Innovative methods in forming performing mastery of students-musicians", Traditsii $i$ novatsii $v$ vysshem akkhitekturno-khudozhestvennom obrazovanii, no.1, pp.82-84, 2016. (in English)

[3] A. Jalil, M. Beer, P. Crowther, "Pedagogical Requirements for Mobile Learning: A Review on MOBIlearn Task Model", Journal of Interactive Media in Education, 2015(1), p.Art. 12. doi: http://doi.org/10.5334/jime.ap. (in English)

[4] G. Thorsteinsson, R. Gunnarsdottir, A. Niculescu, "Assessing the Value of a Mobile Application in Fostering Ideation within a School Context", Studies in Informatics and Control, vol. 24, No. 1, p. 119126, 2015. [Online]. Available: https://opinvisindi.is/bitstream/handle/20.500.11815/450/SIC_2015-1Art13.pdf?sequence=1. Accessed on: Jan.12,2020. (in English)

[5] L.B. Ponce, J. A. J. Méndez, F. J. G. Peñalvo, "First approach of mobile applications study for medical education [Online]. $\quad$ purposes" Available: https://www.researchgate.net/profile/Laura_Briz/publication/268387987_First_approach_of_mobile_appli cations_study_for_medical_Education_purposes/links/54816f7a0cf20f081e727865.pdf. Accessed on: Jan.12,2020. (in English)

[6] N.O. Keskin, A. Kuzu, "Development and testing of a m-learning system for the professional development of academics through design-based action research" [Online]. Available: http://www.irrodl.org/index.php/irrodl/article/view/1613/3194. Accessed on: Jan.12,2020. ( in English)

[7] A.S. Drigas, P. Angelidakis, "Mobile Applications within Education - An Overview of Application Paradigms in Specific Categories", International Journal of Interactive Mobile Technologies, vol. 11, no 4, 2017. [Online]. Available: https://online-journals.org/index.php/i-jim/article/view/6589. Accessed on: Jan.12,2020. ( $n$ English)

[8] C. Luna-Nevarez, E. McGovern, "On the Use of Mobile Apps in Education: The Impact of Digital Magazines on Student Learning”, Journal of Educational Technology Systems, vol. 47(1), pp. 17-31, 2018. [Online]. Available: https://journals.sagepub.com/doi/pdf/10.1177/0047239518778514. Accessed on: Jan.12,2020. (in English)

[9] P. Sagar, "Mobile Apps In The Education Industry: A Productive Approach", 2019. [Online]. Available: https://elearningindustry.com/mobile-apps-in-the-education-industry-productive-approach. Accessed on: Jan.12,2020. ( in English)

[10] N. Shastri, "How Mobile Apps Are Transforming the Education Industry", The Manifest, 2019. [Online]. Available: https://themanifest.com/app-development/how-mobile-apps-transforming-education-industry. Accessed on: Jan.12,2020. ( in English)

[11] M. Osypchuk, "Mobile technologies as prospective field of studying physics" / Proceedings of II International students scientific and technical conference „Natural and Humanitarian sciences. Acute 
topics “, April 25-26, 2019, V : TNTU, p. 188-189, 2019. [Online]. Available: http://elartu.tntu.edu.ua/handle/lib/28402. Accessed on: Jan.12,2020. (in Ukrainian)

[12] I.V. Salnyk, " Mobile devices and modern education software in learning physics in secondary school”, Informatsiini tekhnolohii I zasoby navchannia, vol. 73, №5, p.1-14, 2019. [Online]. Available: https://journal.iitta.gov.ua/index.php/itlt/article/view/2918/1561. Accessed on: Jan.12,2020. ( in Ukrainian)

[13] S. S. Pudova, "Using a Mobile Phone in the Learning Process" / Fiziko-matematichna osvita: scientific magazine. Ministry of Education and Science of Ukraine, Sumy state pedagogical university named after A.S. Makarenka,- Sumy : SDPU Printshop, Vyp. 2 (16), pp. 97-101, 2018. [Online]. Available: https://repository.sspu.sumy.ua/handle/123456789/5412. Accessed on: Jan.12,2020. ( in Ukrainian)

[14] Y.O. Modlo, S.O. Semerikov, P.P. Nechypurenko, S.L. Bondarevsky, O.M. Bondarevska and S.T. Tolmachev, "The use of mobile Internet devices in the formation of ICT component of bachelors in electromechanics competency in modeling of technical objects", Semantic Scholar, pp. 413-428, 2019. [Online]. Available: https://www.semanticscholar.org/paper/The-use-of-mobile-Internet-devices-in-theformation-Modlo-Semerikov/151b9ebf97670c30f8b21420ec5da7362f6afb91. Accessed on: Jan.12,2020. ( in English)

[15] D.V. Borysenko, "Use of mobile applications for developing design-products in training of future experts in design", Informatsiini tekhnolohii I zasoby navchannia, vol. 68, no.6, pp.47-63, 2018. [Online]. Available: https://journal.iitta.gov.ua/index.php/itlt/article/download/2224/1412. Accessed on: Jan.12,2020. ( in Ukrainian)

[16] L. Dybkova, "Prospects of E-learning in the 21st century through the use of mobile devices" / Molod' I rynok, №9 (176), p. 50-54, 2019. [Online]. Available: http://mir.dspu.edu.ua/article/download/182054/181967. Accessed on: Jan.12,2020. (in Ukrainian)

[17] T. Szynalski, "Online Tone Generator - generates pure tones of any frequency". [Online]. Available: https://www.szynalski.com/tone-generator/. Accessed on: Jan.12,2020. (in English)

[18] From Wikipedia, the Free Encyclopedia, "Audio editor". [Online]. Available: https://uk.wikipedia.org/wiki/Аудіоредактор. Accessed on: Jan.12,2020. (in Ukrainian)

[19] B. Bunyk, "How to make a better presentation", 2014. [Online]. Available: https://bunyk.wordpress.com/2014/12/07/how-to-present/. Accessed on: Jan.12,2020. (in Ukrainian)

[20] "Screen mirroring MirrorOp Technology for mobile devices". [Online]. Available: https://www.mirrorop.com/. Accessed on: Jan.12,2020. (in English)

[21] "Mirroring software application for wePresent systems". [Online]. Available: https://www.barco.com/en/product/mirrorop. Accessed on: Jan.12,2020. (in English)

[22] "Canva Software - Collaborate \& Create Amazing Graphic Design For Free". [Online]. Available: https://www.canva.com. Accessed on: Jan.12,2020. (in English)

[23] D. Houston, A. Ferdowski, “Online backup Service”. [Online]. Available: https://uk.wikipedia.org/wiki/Dropbox. Accessed on: Jan.12,2020. (in Ukrainian)

[24] From Wikipedia, the Free Encyclopedia, "Pixel Density". [Online]. Available: https://uk.wikipedia.org/wiki/Dots_per_inch. Accessed on: Jan.12,2020. (in Ukrainian)

[25] From Wikipedia, the Free Encyclopedia, "Comscore -media measurement and analytics company". [Online]. Available: https://en.wikipedia.org/wiki/Comscore. Accessed on: Jan.12,2020. (in Ukrainian)

[26] K. Lewis, "Global State of Mobile", Comscore Whitepaper, 2019. [Online]. Available: https://www.comscore.com/Insights/Presentations-and-Whitepapers/2019/Global-State-of-Mobile. Accessed on: Jan.12,2020. (in English) 